there no First Amendment right to remain silent, the Court would not have had to know the legislative need for the investigation in order to determine whether there had been a First Amendment violation. On the other hand, if a First Amendment right were really involved, it would seem that few legislative needs would justify investigations infringing this right, and the present Court seems unlikely to find such a need in regard to legislation concerning subversion. Perhaps the Court in Watkins wished to avoid the problem of balancing the basic conflict between a right to privacy of belief and the legislative need for information. However, the Court's holding that the First Amendment is applicable requires that eventually this problem be faced, and indicates that, even where a committee with a valid legislative purpose asks questions clearly pertinent to a precise authorizing resolution, there may still be First Amendment limitations on questions concerning the witness's political associations and beliefs.

\title{
THE RIGHT OF PEREMPTORY CHALLENGE
}

Every American jurisdiction provides by statute ${ }^{1}$ that parties to a civil or criminal proceeding are entitled to reject a certain number of prospective jurors $^{2}$ without assigning cause. Through the exercise of this right to peremp-

1 "In civil cases, each party shall be entitled to three peremptory challenges. Several defendants or several plaintiffs shall be considered as a single party for the purposes of making challenges." 62 Stat. 953 (1948), 28 U.S.C.A. $\$ 1870$ (1948). "If the offense charged is punishable by death, each side is entitled to 20 peremptory challenges. If the offense charged is punishable by imprisonment for more than one year, the government is entitled to 6 peremptory challenges and the defendant or defendants jointly to 10 peremptory challenges. If the offense charged is punishable by imprisonment for not more than one year or by fine or both, each side is entitled to 3 peremptory challenges." Fed. Rules Crim. Proc. 24(b).

No constitutional basis is recognized for the right of peremptory challenge. "[I]n criminal cases; trial by an impartial jury is all that is secured." Stilson v. United States, 250 U.S. 583, 586 (1919). There is even less constitutional support for peremptory challenges in civil cases, since an impartial jury is not guaranteed, as it is in criminal cases by the Sixth Amendment. The Seventh Amendment reads: "In suits at common law ... the right of trial by jury shall be preserved."

This apparently more solicitous attitude toward a criminal defendant is reflected by the fact that in federal courts and in all states, with one or two possible exceptions, more peremptory challenges are allowed in criminal cases than are allowed in civil cases. One exception is Vermont, which allows the same number of challenges in any proceeding in any court. Vt. Rev. Stat. (1947) \$1726.

For examples of state peremptory challenge statutes, consult Cal. Code Civ. Proc. (Deering, 1953) $\$ 601$, Cal. Penal Code (Deering, 1949) $\$ \$ 1070,1070.5 ;$ Ill. Rev. Stat. (1955) c. $110, \S 66$, c. $38, \$ 742$; N.Y. Civ. Prac. Act (1920, as amended to 1956) $\$ 451$, N.Y. Crim. Code (1881, as amended to 1953 ) $\$ 373$. Rhode Island is exceptional in not allowing peremptory challenges in criminal proceedings in which the defendant is charged with treason, murder, robbery, rape, arson, or burglary. R.I. Laws (1938) c. $625 \$ \$ 17,67$. That state does allow peremptory challenges in civil cases and other criminal cases, however. R.I. Laws (1938) c. 507, \$2.

"Hereafter, the word "veniremen" is often used instead of "prospective jurors." 
tory challenge, countless persons reporting for jury service are excused, although no showing is made of their partiality or incompetence. This practice is so firmly embedded in accepted trial practice and the popular imagination that it has escaped critical examination. ${ }^{3}$ It is the purpose of this comment to discuss, with primary emphasis on federal courts, four problems which arise in connection with the peremptory challenge: whether the number of challenges allowable in a trial should depend on the number of parties or actions involved; whether there should be any limitation as to the time by which a challenge must be exercised, apart from the accepted limitation that jurors must be challenged before they are sworn; whether prejudice must be shown in order to obtain a new trial for denial of the right to challenge; and whether any limitation can be imposed on a discriminatory exercise of challenges. Analysis of these problems raises the question of the basic justification for granting peremptory challenges.

Number of challenges.-Almost every federal peremptory challenge case in which a new trial was granted involved the question of how many challenges a party is entitled to exercise. ${ }^{4}$ Difficulties have arisen mainly in two situations: trials involving more than one plaintiff or defendant, and trials involving several claims or offenses. ${ }^{5}$

${ }^{3}$ Information concerning the early history of the right of peremptory challenge is limited.
What information is available indicates that at common law there was no right of peremp-
tory challenge in civil cases. The right did exist in certain criminal proceedings, however,
such as those involving felony, treason, or misprision of treason. In these cases the defendant
was allowed 35 peremptory challenges. "Why this particular number was pitched upon is a
matter of uncertainty which it would be profitless to investigate, as the old writers afford
little in the way of cogent reasons for their choice. The number is probably arbitrary, like
the challenge itself." Thompson and Merriam, The Organization, Custody and Conduct of
Juries, 136 (1882).

Subsequent statutes reduced the number of peremptory challenges allowed in cases of felony and petit treason to twenty. 22 Henry VIII, c. 14, $\$ 6(1530) ; 32$ Henry VIII, c. 3 (1540). Also, in Gray v. Regina, 11 Cl. \& Fin. 427 (M. L., 1843), it was settled that at common law the right to peremptory challenges existed in all cases of felony and was not restricted to trials of crimes punishable by death.

The Crown had an unlimited right to challenge peremptorily until it was restricted by statute to challenges for cause. $33 \mathrm{Edw}$. I, c. 2 (1305). In practice the effect of this statute was mitigated, because the Crown was not required to show cause against a prospective juror at the time of challenge. Instead the Crown could direct a prospective juror to stand aside. When challenging was completed by both the Crown and the accused, if enough persons remained on the panel to form a jury, the Crown did not have to show cause as to those who had been asked to stand aside. Otherwise the Crown then had to show cause as to these persons. This practice continues in England today. Consult 6 Geo. IV, c. $50, \$ 29$ (1825).

' E.g., Mutual Life Ins. Co. v. Hillmon, 145 U.S. 285 (1892); Signal Mountain Portland Cement Co. v. Brown, 141 F.2d 471 (C.A.6th, 1944); Davis v. Jessup, 2 F.2d 433 (C.A.6th, 1924); Gallaghan v. United States, 299 Fed. 172 (C.A.8th, 1924); Butler v. Evening Post Publishing Co., 148 Fed. 821 (C.A.4th, 1906); Betts v. United States, 132 Fed. 228 (C.A.1st, 1904).

${ }^{5}$ Hereafter, the former situation is referred to as a multiple-party case, and the latter situation as a multiple-action proceeding, irrespective of whether they are civil or criminal in nature. 
In multiple-party cases, assuming that the several plaintiffs or defendants are properly joined, ${ }^{6}$ there appears to be little ground for dispute over the number of peremptory challenges. Section 1870 of the federal Judicial Code provides that in civil cases "each party" is entitled to a specified quota of challenges and that "(s)everal defendants or several plaintiffs shall be considered as a single party for the purpose of making challenges." In criminal cases, "each side" receives a certain number of challenges, and the defending side may contain more than one party. ${ }^{8}$

It is up to the parties on each side to work out their allotment of challenges, since a peremptory challenge by one party counts as a challenge by all his coparties. ${ }^{9}$ Multiple parties have no right to have their challenges apportioned among them; ${ }^{10}$ the peremptory challenge statutes do not give a court authority to make such apportionment; ${ }^{11}$ except as to additional challenges, which may be given to defendants at the court's discretion. ${ }^{12}$

Although the single-party rule (i.e., that several plaintiffs or defendants are a single party) may seem harsh, especially in cases involving a great number of parties on one side, ${ }^{13}$ the rule is desirable from the standpoint

- For the rules concerning joinder of plaintiffs and defendants in civil case, consult Fed. Rules Civ. Proc. 20(a), and 3 Moore's Federal Practice 2722-25 (2d. ed., 1948). With respect to joinder of defendants in criminal cases, consult Fed. Rules Criminal Proc. 8(b).

762 Stat. 953 (1948), 28 U.S.C.A. $\$ 1870$ (1948).

${ }^{8}$ Consult note 1 supra. This is also the law in several states. Consult, e.g., Ind. Stat. Ann. (Burns, 1956), \$\$2-2-6, 9-1502, 9-1503; Wash. Rev. Code (1951) $\$ \$ 4.44 .130,10.49 .060$.

- Stilson v. United States, 250 U.S. 583 (1919). This case has been followed consistently. Consult, e.g., Schaefer v. United States, 251 U.S. 466 (1920) ; Holmes v. United States, 134 F.2d 125 (C.A.8th, 1943), certiorari denied 319 U.S. 776 (1943) ; Solomon v. United States, 297 Fed. 82 (C.A.1st, 1924).

${ }^{10}$ Wilkes v. United States, 291 Fed. 988 (C.A.6th, 1923).

${ }^{11}$ Nevertheless, apportionment was upheld in Schwartzberg v. United States, 241 Fed. 348 (C.A.2d, 1917). In that case fourteen defendants were represented by numerous counsel, who refused to act jointly in using the ten challenges to which they were entitled. Consequently, the trial court allowed each defendant one peremptory challenge, so that the defendants were given a total of fourteen challenges. Subsequent efforts of some defendants to exercise more than one challenge were disallowed. The appellate court held that the refusal of several defendants to act jointly in exercising challenges does not render the exercise of the right by others illegal, but that in such a case it is not error to apportion challenges among individual defendants.

${ }^{13}$ Consult note 15 infra for a discussion of a court's discretion to give additional challenges.

${ }^{18}$ In United States v. Macke, 159 F.2d 673 (C.A.2d, 1947), three defendants were held properly convicted although they had shared their peremptory challenges with fifteen other defendants who pleaded guilty before trial, but after the jury was sworn. The court considered that once the jurors were sworn the position of the remaining defendants was just as good after the guilty pleas as before, even though they had been forced to share their challenges with fifteen defendants who were not tried by the jurors. It seems most impractical to have any other rule. That is, if a change in the position of some litigants after a jury has been sworn requires a trial court to allow the remaining parties to start afresh and impanel a new jury, additional expense and delay would result and defendants could conspire to conduct their defense in such a way that trial could be deferred until they obtained a jury which satisfied them. 
of practicality and convenience. Otherwise, in cases involving several parties, a great many more persons would have to be called for possible jury service. ${ }^{14}$ Proceedings would be more costly and time-consuming. ${ }^{15}$

${ }^{14}$ See State v. Cady, $80 \mathrm{Me} .413,14$ Atl. 940 (1888). Yet several states provide that a
person who is a party to a trial has a prescribed number of peremptory challenges for his
personal use, whether he is the only one tried or one of several being tried at the same time.
For example, Florida applies this rule in both civil and criminal cases. Fla. Stat. (1955)
$\$ \$ 54.11,913.08$. Illinois applies the rule in criminal cases and leaves its application discre-
tionary with the court in civil cases. Tll. Rev. Stat. (1955) c. 110, $\$ 66$, c. 38 , $\$ 742$. Ohio, as
well as several other states, reflects the tendency to provide more protection for criminal
defendants (consult note 1 supra) by applying the rule only in criminal cases. Ohio Rev.
Code (Baldwin, 1953) $\$ \$ 2313.44,2945.21,2945.22$. All of these statutes specify that each side receives an equal number of peremptory challenges.

Other states attempt to maintain a balance between the positions of allowing too many challenges and allowing too few challenges when there are multiple defendants. Colorado allows a certain number of challenges for the first defendant and a fraction of that number for each additional defendant, up to a maximum figure. Colo. Rev. Stat. (1953) §78-5-4. Texas allows each of several defendants half as many challenges as are allowed a single defendant. Texas Code of Civ. Proc. (Vernon, 1941) Art. 615, 634, 635.

${ }^{15}$ The foregoing problems with respect to defendants are not likely to arise as often anymore in federal courts, since, in 1948, additions to $\$ 1870$ of the Judicial Code and Criminal Rule 24(b) provided that in federal-court cases where "there is more than one defendant, the court may allow the defendants additional peremptory challenges and permit them to be exercised separately or jointly." Consult, e.g., United States v. Fujimoto, 107 F.Supp. 865 (D. Hawaii, 1952) (each of seven defendants were granted one additional challenge, instead of the two requested).

It is not clear under what circumstances a refusal by the trial court to award additional challenges will constitute sufficient abuse to warrant a new trial. A new trial was awarded in Globe Indemnity Co. v. Stringer, 190 F.2d 1017 (C.A.5th, 1951), a civil action in which the trial court, in response to a question by counsel for one of the two defendants, indicated that each defendant would have three peremptory challenges-the statutory quota for one party in a civil action. This counsel then exercised three challenges, and counsel for the other defendant then attempted to exercise a challenge. The court refused to allow this defendant any challenges, however, because the quota was three challenges and the court believed it had no power to allow additional challenges. The appellate court rested its reversal on the notion that what was involved was non-exercise of discretion, and this was held to constitute error as a matter of law. In addition, it should be noted that the appellant was misled by the trial court, and the decision might have been rested on this ground as well. Language in the opinion, however, indicates that "arbitrary" or "unreasonable" exercise of the discretion would be grounds for a new trial.

No state has been found which gives its courts discretion to allow additional challenges in both civil and criminal cases. A few states which allow each defendant in a criminal trial a full quota of peremptory challenges give their courts such discretion in civil cases. Consult, e.g., Ill. Rev. Stat. (1955) c. 110, $\$ 66$. Some states give their courts such discretion only in criminal cases. Consult, e.g., Del. Code Ann. (1953) vol. 13, Rules of Crim. Proc. 24(b).

There are statutes which make the allowance of additional challenges discretionary with the court provided certain conditions are satisfied. E.g., Wisconsin gives its courts discretion to grant additional peremptory challenges to defendants in civil cases "where ... defendants have adverse interests [and the court is] satisfied that the due protection of their interests so requires," and in criminal cases "if their defenses are adverse and the court is satisfied that the protection of their rights so requires." Wis. Stat. (1955) $\$ \$ 270.18,957.03$. And, in civil cases in Ohio, peremptory challenges allowed "each party" by statute should be given to each litigant if their interests are essentially different or antagonistic. Christoff v. Dugan, 39 Ohio App. 475, 177 N.E. 895 (1931). 
Moreover, in many situations the single-party rule does not prejudice multiple parties. The proper test of prejudice under the single-party rule is whether the rule forces any co-party to trial before a jury some members of which he would have challenged had he been on separate trial. Thus, the basic question is whether each co-party wishes to challenge the same veniremen. If so, then allowing one side more than the single-party quota would give parties a windfall; they could eliminate from the panel veniremen in addition to those that would have been eliminated in a separate trial of any one of the co-parties. If, on the other hand, co-parties disagree on which veniremen should be challenged, allowing only the single-party quota to a side forces some co-parties to forego challenges they would have made on separate trial.

The extent to which co-parties will agree on how peremptory challenges should be exercised must, in the nature of the situation, be largely a matter of conjecture; for the question depends on the reasons for which these challenges are exercised-reasons which it is the function of the peremptory challenge to protect from disclosure. If the reasons pertain to veniremen's reaction to the facts of the case, rather than to their reaction to particular co-parties, then coparties should be able to agree on which veniremen to challenge. For instance, a venireman with a strong bias in favor of large verdicts probably would be challenged by any co-defendant, while perhaps only one co-party would challenge a venireman with a prejudice against his particular race or religion.

It seems clear that in any particular multiple-party case the decision as to whether one side should recieve more than the single-party quota cannot rest on the reasons why peremptory challenges will be exercised in that case, since this would force parties to disclose their reasons. The trial judge, in his discretionary allotment of additional challenges, ${ }^{16}$ might guess the parties' reasons for exercising peremptory challenges and make an additional allotment without forcing disclosure. Alternatively, a general rule, independent of the reasons for challenge in any particular case, might be formulated to avoid substantial prejudice to multiple parties in most cases, if it could be found what reasons generally cause lawyers to exercise peremptory challenges. But absent a showing that it causes substantial prejudice to multiple parties in most cases, the single-party rule appears to be desirable; any prejudice which it does cause may be balanced by considerations of practicality and convenience.

A problem as to number of peremptory challenges also arises in multipleaction proceedings, involving either one or several parties on each side. The problem, not dealt with by the statutes, is whether the number of peremptory challenges should depend upon the number of claims or offenses before the jury. ${ }^{17}$

${ }^{18}$ Consult note 15 supra.

${ }^{17} \mathrm{~A}$ related problem is whether the number of challenges should depend upon the number of indictments or complaints before the jury. In federal criminal proceedings, several indictments can properly be tried together if all the offenses and defendants could have been 
It can be argued that the statutory quota for each offense or claim should be allowed where several offenses or claims, tried before a single jury, could have been brought and tried separately. ${ }^{18}$ In these cases the trial of several claims or offenses at the same time has made possible a saving to the state, for which it might seem that the parties should not be penalized by a reduction of their challenges below the number they would be allowed on separate trial. However, parties will probably suffer no prejudice from such a reduction, for it would seem that the presence of additional offenses or claims before a single jury would have little effect on the jurors' partiality, so as to increase the number of veniremen whom parties would wish to challenge. Moreover, if prejudice does appear, the trial court may order additional challenges or severance, under both the Civil and Criminal Rules. ${ }^{19}$ Finally, it may be noted that allotting the quota of challenges for each claim or offense in a case operates to give the same number of additional challenges to each side. Therefore, parties in multiple-action cases may be indifferent as to whether challenges are allowed on the basis of the number of claims or offenses involved. Since the advantage to one side of receiving additional challenges may well be cancelled by the allowance to the opposing side of an equal number of addi-

joined in a single indictment; and upon trial together, "[t]he procedure shall be the same as if the prosecution were under single indictment." Fed. Rules Crim. Proc. 13. Thus, each side is usually given only the number of challenges allowed for the trial of a single indictment. Beckett v. United States, 84 F.2d 731 (C.A.6th, 1936); Kharas v. United States, 192 Fed. 503 (C.A.8th, 1911) ; see Kettenbach v. United States, 202 Fed. 377 (C.A.9th, 1913); Emanuel v. United States, 196 Fed. 317 (C.A.2d, 1912); Krause v. United States, 147 Fed. 442 (C.A.8th, 1906). A few cases, however, have allowed the full statutory quota for each of several indictments tried together. Gallaghan v. United States, 299 Fed. 172 (C.A.8th, 1924) ; Betts v. United States, 132 Fed. 228 (C.A.1st, 1904). In federal civil proceedings, it has been held that, where several complaints are tried together, the parties are entitled to the full quota of challenges for each complaint, although there is language indicating that an opposite result would obtain had the complaints been consolidated. Mutual Life Ins. Co. v. Hillmon, 145 U.S. 285 (1892) ; United Verde Copper Co. v. Jordan, 14 F.2d 299 (C.A.9th, 1926) ; Davis v. Jessup, 2 F.2d 433 (C.A.6th, 1924) ; Butler v. Evening Post Publishing Co., 148 Fed. 821 (C.A.4th, 1906); Conn. Mutual Life Ins. Co. v. Hillmon, 107 Fed. 834 (C.A.8th, 1901). As a matter of policy it would seem undesirable to draw a distinction, for peremptory challenge purposes, between consolidation into one indictment or complaint and trial together of numerous indictments or complaints. The difference between the two procedures seems to be merely in the form of judgment. At most, under the former procedure a single verdict is rendered on the merged issues, whereas under the latter procedure a separate verdict is rendered for each indictment or complaint. George v. Leonard, 84 F.Supp. 205 (E.D.S.C., 1949) ; Bley v. Travelers Ins. Co., 27 F.Supp. 351 (S.D.Ala., 1939).

${ }^{18}$ Trial before separate juries may be had where several claims between a single plaintiff and defendant do not arise out of the same transaction, Blume, Required Joinder of Claims, 45 Mich. .. Rev. 797, 797-803 (1947), or where several claims between several plaintiffs and defendants do not involve interests which under Rule 19 make the parties to the claims necessary or indispensable to an action on any one of the claims. In criminal proceedings, separate trials may be had for each separate offense. On the scope of the "offense," consult Kircheimer, The Act, the Offense, and Double Jeopardy, 58 Yale L. J. 513 (1949).

${ }^{10}$ Fed. Rules Civ. Proc. 42(b) ; Fed. Rules Crim. Proc. 14. Consult note 15 supra. 
tional challenges, there would seem to be no reason why any different rule concerning the number of peremptory challenges should be followed in multiple-action trials, as compared with single-action trials.

Time of exercise.-One important procedural problem in the field of peremptory challenge concerns the number of veniremen which a party may examine ${ }^{20}$ before he must decide finally to accept or to challenge those examined. Usually a party is allowed to defer peremptory challenges until several veniremen have been examined and not successfully challenged for cause. ${ }^{21}$ Yet it has been held that the trial court may require each venireman to be examined separately and to be finally challenged or accepted before examination of another venireman. ${ }^{22}$ This holding deprives a party of the opportunity intelligently to compare several veniremen before exercising any challenges. ${ }^{23}$ In some situations a party may not need to compare; he may have such strong objection to a particular venireman that he is willing to reject without comparison to the rest of the panel. However, in many cases a party will be unable to tell whether other veniremen might not be more objectionable and thus more worthy of challenge. In any event, there would seem no reason to require the exercise of any peremptory challenges until twelve veniremen have been examined and not successfully challenged for cause; ${ }^{24}$ in order to select any jury, at least twelve veniremen will have to be examined. Conversely, it may well involve unnecessary expense to allow examination of more than twelve without challenge; it may turn out that the additional veniremen were not needed.

Once it is decided when a particular venireman must be either challenged or finally accepted, there still remains the question of when a particular challenge must be either exercised or waived. In trials of an offense for which the de-

\footnotetext{
${ }^{20}$ Note that a federal court may itself conduct the examination of prospective jurors if it chooses. Fed. Rules Civ. Proc. 47 (a) ; Fed. Rules Crim. Proc. 24(a).

${ }^{\dddot{x}}$ Avila v. United States, 76 F.2d 39 (C.A.9th, 1935); see Wilkes v. United States, 291 Fed. 988, 991 (C.A.6th, 1923); Radford v. United States, 129 Fed. 49 (C.A.2d, 1904); Emanuel v. United States, 196 Fed. 317 (C.A.2d, 1912). But the cases indicate that a party has no right to have all available veniremen examined. Browne v. United States, 145 Fed. 1 (C.A.2d, 1905).

${ }^{20}$ St. Clair v. United States, 154 U.S. 134 (1894).

${ }^{2}$ In Tierney v. United States, 280 Fed. 322 (C.A.4th, 1922), where the defendant was denied the right to have twenty-eight veniremen presented together for challenge, the court said: "The opportunity for comparison of jurors is greater when 12 are presented at once than under the common-law method of presenting each juror separately. The complaint against either method is met by the principle, so often repeated, that the right of challenge is a right of rejection, not of choice." Id., at 324.

${ }^{26}$ As to the system of examining veniremen, if the examination is not conducted by the court, one may well decide that veniremen should be presented in small panels, of four or six, for example. It probably is less burdensome for counsel if the parties can alternate in examining a few veniremen at a time, rather than if one party is required to examine twelve veniremen in succession.
} 
fense is allowed more challenges than the prosecution, ${ }^{25}$ an alternating system of exercise has been used, ${ }^{26}$ whereby each side must in turn exercise a prescribed number of peremptory challenges; when the turn comes, this number must be either exercised on the panel as presently constituted or these challenges are waived. This practice is upheld on the theory that it does not deprive a party of any challenges but merely requires that they be exercised at a particular time. ${ }^{27}$

Presumably, the alternating system is used in cases where the sides have an unequal number of challenges so that one side will not have several challenges left when the other side's challenges are exhausted. In this situation, the side with challenges remaining might, by appropriate exercise of these challenges, bring onto the panel several veniremen whom the other side would have challenged peremptorily had it had the chance. However, there appears to be no alternating system in use for civil or criminal cases where both sides are given an equal number of challenges. In those cases parties exercise challenges when they choose, and one side may have several challenges left after the other side's challenges have been exhausted.

The alternating system seems to limit unnecessarily the exercise of challenges to the membership of a panel at a particular time. No strong policy appears to justify such a limitation, and the peremptory challenge statutes do not authorize it; rather they merely provide a certain number of challenges without limitations as to time and order of exercise.

Right to a new trial.-Assuming the trial court commits error in its peremptory challenge procedure, a problem remains as to what prejudice the complainant ${ }^{28}$ must show in order to obtain a new trial. The problem may be con-

2s "If the offense charged is punishable by imprisonment for more than one year, the government is entitled to 6 peremptory challenges and the defendant or defendants jointly to 10 peremptory challenges." Fed. Rules Crim. Proc. 24(b).

${ }^{23}$ United States v. Keegan, 141 F.2d 248 (C.A.2d, 1944); Philbrook v. United States, 117 F.2d 632 (C.A.8th, 1941) Contra: United States v. Daubner, 17 Fed. 793 (E.D. Wis., 1883).

${ }^{27}$ United States v. Keegan, 141 F.2d 248, 255 (C.A.2d, 1944).

$\approx$ The complaining party must have acted in a manner which qualifies him to complain. In Krause v. United States, 147 Fed. 442 (C.A.8th, 1906), where several indictments against two defendants were heard by the same jury, defendants contended that the trial court erred in stating they were entitled to only three challenges. But the court said, "the defendants did not place themselves in position to complain of the statement of the court at the trial, as they made no peremptory challenge whatever." Id., at 446 . This recognition of a party's failure to place himself in a position to complain has also appeared in cases where some but not all of the available peremptory challenges were exercised. Connecticut Mutual Life Ins. Co. v Hillmon, 188 U.S. 208 (1903) ; Kloss v. United States, 77 F.2d 462 (C.A.8th, 1935); Tierney v. United States, 280 Fed. 322 (C.A.4th, 1922); United Mine Workers of America v. Coronado Coal Co., 258 Fed. 829 (C.A.8th, 1919); Richards v. United States, 175 Fed. 911 (C.A.8th, 1909). Apparently the reasoning is that in not using all peremptory challenges to which he is entitled, a party thereby acquiesces in the composition of the jury, because by exercising those peremptory challenges which he did not exhaust, "he could ... have thus rid himself of those to whom he objected." Kloss v. United States, supra at 464; see Simpson v. United States, 184 Fed. 817, 819 (C.A.8th, 1911). 
sidered in two parts: whether it must be shown that the error affected the composition of the jury; and, assuming an effect on composition, whether it must be further shown that the outcome of the trial was probably affected.

An error in the order of challenge- where one party is erroneously made to exercise his challenges before the other-is an example of an error which may have no effect on jury composition. ${ }^{29}$ The party who was made to challenge first might have profited from the other party's examination and challenges, but this cannot be clearly shown.

Improper limitation on the number of challenges, and improper denial of a right to challenge veniremen in an accepted panel, are examples of errors clearly affecting jury composition. However, it would be virtually impossible to show that such errors affected the verdict. Courts are extremely reluctant to allow jurors to testify as to occurrences during jury deliberations. ${ }^{30}$ And even if a transcript of the deliberations were available, it would seem virtually impossible to tell whether a particular juror "affected" the group decision. If the test of prejudice is simply which way the juror voted, it could be argued that any other juror probably would have voted the same way, since the challenged juror must have voted with the majority. A test of prejudice requiring that the challenged juror exercise a controlling influence on the votes of others would be vague and extremely difficult to apply. Perhaps the only solution to the problem is a rule of automatic prejudice.

Since there is no way for a party deprived of his peremptory challenge to show prejudice, there is no sanction to enforce his right unless violation thereof is adjudged automatically prejudicial. Moreover, there are times when reversal is necessary to secure compliance with the law in future cases. . . The danger of ... holding the error harmless ... is that it becomes entrenched as a precedent, inviting future violation of the rule. ${ }^{31}$

This reasoning might also be applied to errors which cannot be proved to have affected jury composition, although here a court might well feel that the remoteness of the possibility of prejudice from this error outweighs the policy of deterring such errors in future cases.

Discriminatory exercise.-Since the heart of the right to exercise peremptory challenges is the power to excuse a juror without assigning any reason

${ }^{20}$ Cf. Emanuel v. United States, 196 Fed. 317 (C.A.2d, 1912).

${ }^{\text {so }}$ Consult Wigmore, Evidence $\$ \$ 2348-56$ (3d ed., 1940).

"Traynor, Some Open Questions on the Work of State Appellate Courts, 24 U. of Chi. L. Rev. 211, 222 (1957). In this connection Justice Traynor discusses Buckley v. Chadwick, 45 Cal.2d 183, 289 P.2d 242 (1955), where a majority held that in a civil action requiring the vote of only nine jurors for a verdict, improper denial of a peremptory challenge was harmless error. A contrary result would probably be reached where a unanimous verdict is required. This distinction between unanimous and non-unanimous verdicts seems without justification. Where unanimity is not required, there would be virtually as much possibility that the challenged juror gave the deciding vote or brought about the verdict by influencing the votes of other jurors. 
whatsoever, the manner of exercise cannot be successfully assailed as arbitrary or discriminatory. An extreme example of discrimination appears in Hall $v$. United States, ${ }^{32}$ where the government, in a prosecution of three Negroes for the murder of a white man, exercised nineteen of its twenty peremptory challenges to exclude all Negro veniremen from the jury. On appeal a divided court affirmed the conviction, holding that the government's action did not constitute a violation of due process, because there had been no discrimination in the selection of veniremen.

Critics of the Hall decision contend that there is a doctrinal inconsistency in prohibiting discrimination in one phase of jury formation-the selection of veniremen ${ }^{33}$-while allowing discrimination in another phase-the assembly of a jury from these veniremen. Some writers suggest that racial discrimination through the peremptory challenge should be grounds for a new trial, and they propose that courts consider certain tests in determining whether there has been such discrimination: 1) whether the number of Negroes challenged bears a large proportion to the number of Negro veniremen and to the number of total challenges; 2) whether the prosecution over a period of time has consistently challenged all Negroes; 3 ) whether the prosecution admits challenging Negroes because of their race. ${ }^{34}$

Unfortunately, the proposed tests for detecting discrimination are not helpful. Under the proportion tests it is difficult to decide: 1) if the number of Negro veniremen is relatively small and all are challenged, whether this constitutes discriminatory challenging on the basis of race; or 2) if less than all Negro veniremen are challenged, what proportion the number challenged must bear to the total of all Negro veniremen before it is reasonable to conclude that there has been discrimination. The past history test only applies to cases involving a party who has consistently challenged all Negro veniremen over a period of time, and few parties other than the government would satisfy this requirement. If a party challenged all Negro veniremen in several cases, however, one must still decide whether, and at what point, there is discrimination. Also, it seems inconsistent to award a new trial for discriminatory challenging in one case on the basis of prior cases, involving the same conduct, in which

${ }^{32} 168$ F.2d 161 (App. D.C., 1948), cert. denied 334 U.S. 853 (1948).

${ }^{33}$ Hill v. Texas, 316 U.S. 400 (1942); Smith v. Texas, 311 U.S. 128 (1940); Pierre v. Louisiana, 306 U.S. 354 (1939) ; Hale v. Kentucky, 303 U.S. 613 (1938) ; Norris v. Alabama, 294 U.S. 587 (1935). Consult Jefferson, Race Discrimination in Jury Service, 19 B.U.L. Rev. 413 (1939). "No citizen possessing all other qualifications which are or may be prescribed by law shall be disqualified for service as grand or petit juror in any court of the United States, or of any State on account of race, color, or previous condition or servitude. ..." 62 Stat. 696 (1948), 18 U.S.C.A. $\$ 243$ (1948).

3t Peremptory Challenging of Negro Veniremen as Discrimination against Negro Criminal Defendant, 24 Ind. L. J. 262, 270, 271 (1949); Jury-Challenges and Objections-Challenging Peremptorily All Negroes on Jury Panel by Federal Prosecutor Held Not Improper, 61 Harv. L. Rev. 1455, 1457 (1948). 
no new trial was granted. Finally, a party is not likely to admit that he challenges solely on the basis of race, if such an admission will be held to be the basis for granting a new trial.

The Hall decision seems entirely consistent with the policy of the peremptory challenge to permit parties to excuse veniremen without assigning cause. It would seem that a court has no way effectively to control parties' choice of whom to challenge peremptorily. Yet, if the peremptory challenge requires results such as that reached in the Hall case, one may well wonder why the peremptory challenge continues to command unquestioned acceptance.

The rationale of the peremptory challenge.-The peremptory challenge is a puzzling institution. To an observer not imbued with Anglo-American trial tradition it would seem strange that courts should sanction dismissal of prospective jurors against whom challenging parties cannot formulate legally acceptable objections. It is argued that objections to a venireman can be difficult to prove. However, this argument shows only that the law of challenge for cause may be too stringent and that the requirements for proving cause should be relaxed where challenge rests on grounds inherently difficult to prove. ${ }^{35}$ Difficulty of proof should not prevent challenging counsel from making the most plausible arguments possible under the circumstances.

It would seem that the basic justification for having the peremptory challenge goes beyond a fear that challenging counsel could not prove his objections sufficientily to get within a rational law of challenge for cause. There seems to be involved an ambivalence on the part of courts toward the reasons for which the peremptory challenge is often exercised. It is well known that challenges are often exercised on the basis of race, religion and nationality; it would seem such challenges should be allowed, since they probably are

${ }^{35}$ A challenge might be made upon a ground of absolute disqualification or, even though the juror is qualified, for actual or implied bias. The former is technically a challenge for "cause" and the latter "for favor"-both terms being retained in $\$ 1870$ of the 1948 Judicial Code. See United States v. Wood, 299 U.S. 123, 133-35 (1936) (dealing with actual or implied bias of government employees as jurors in a criminal case). The qualifications for jurors in federal cases are provided by statute and include grounds of disqualification provided by the law of the state where the district court is located. 62 Stat. 951 (1948), 28 U.S.C.A. $\$ 1861$ (1948).

Illustrations of unsuccessful attempts to challenge a juror for actual or implied bias upon grounds that would almost certainly provoke a peremptory challenge are numerous. E.g., United States v. Dennis, 183 F.2d 201, 228 (C.A.2d, 1950) (illustrating the general rule that a juror who has read of the case and formed a provisional opinion is not disqualified if he believes he could change his mind after hearing the evidence); Anderson v. Todd Shipyard Corp., 63 F.Supp. 229 (S.D.N.Y., 1945) (employee of liability insurance company which did not cover defendant held not disqualified, although he would be if employed by defendant's insurer) ; Kelly v. Gulf Oil Corp., 28 F.Supp. 205 (E.D.Pa., 1938) (acquaintance or professional relationship with a witness does not disqualify a juror); and see Garland v. United States, 182 F.2d 801 (C.A.4th, 1950) (indicating that family relationship to the prosecuting attorney will not disqualify a juror). The availability of the right of peremptory challenge makes it easier for the courts to decide that these challenge attempts are not valid. 
necessary, in many situations, to eliminate bias in the jury. Yet courts may well be reluctant to sustain challenges for cause based on these grounds; a holding that race, religion and nationality are legally acceptable causes for challenge would give too explicit a sanction to a type of discrimination elsewhere disapproved by the law. The peremptory challenge has avoided the necessity for such holdings; in the cases found, challenges based on the race, religion or nationality of veniremen seem to have always been peremptory. ${ }^{36}$

Another justification for the peremptory challenge may be suggested. The availability of peremptory challenges may be a means of satisfying litigants that they are being tried by an impartial jury. Allowing litigants to participate in the selection of their jury tends to prevent them from feeling that the composition of the jury is completely in the hands of the judge, in his allowance of challenges for cause. While perfect administration of a rational law of challenge for cause would guarantee impartial juries, there will inevitably be many cases in which complete impartiality is not achieved, and there will be even more cases in which parties feel that the jury was not impartial. It may seem unusual for the legal order to assume that one branch of the law will not be properly applied in a significant number of cases and will be considered by the parties in even more cases to have been applied unfairly. But the right to trial by jury is fundamental to our society, and in order to preserve this right it is important that litigants feel juries are impartial. The peremptory challenge tends to persuade litigants of the fairness of juries and thus has an important role to play in the preservation of the jury system.

${ }^{\text {s8 }}$ Hall v. United States, 168 F.2d 161 (App. D.C., 1948); People v. Roxborough, 307 Mich. 575, 12 N.W.2d 466 (1943), cert. denied 323 U.S. 749 (1944); State v. Logan, 344 Mo. 307, 126 S.W.2d 256 (1939); Whitney v. State, 43 Tex. Crim. 207, 63 S.W. 879 (1901).

\section{NO-CONTEST WILI CLAUSES}

The typical no-contest will clause provides that if a devisee or legatee contests the validity of any part of the will, the devise or legacy which he would otherwise receive shall pass to another. ${ }^{1}$ The extent to which these

\footnotetext{
${ }^{1}$ Consult, e.g., In re Estate of Hartz, 247 Minn. 362, 363, 77 N.W.2d 169, 170 (1956) (". . . Should any legatee herein directly or indirectly contest the validity of this Will and Testament in any manner, then any bequest, legacy and devise ... hereinbefore made in favor of such person or persons shall be void and of no effect and such bequest, legacy and devise shall go to the St. Peter's and St. Paul's Catholic Church of Mazeppa, Minnesota, ..."). In some jurisdictions if the no-contest clause fails to contain a limitation or gift over, the clause is said to be merely in terrorem. Consult, e.g., Ga. Code Ann. (1937) \$113-820; Smithsonian Institution v. Meech, 169 U.S. 398, 413 (1898); Sherwood v. McLaurin, 103 S.C. 370,88 S.E. 363 (1916). Professor Browder deprecates the in terrorem doctrine in his two articles, Testamentary Conditions Against Contest Re-examined, 49 Col. L. Rev. 320, 339 (1949) ("this medieval hoax"), and Testamentary Conditions Against Contest, 36 Mich. L. Rev. 1066, 1093 (1938) ("a grotesque fiction"). Consult Kertz, Contesting a Will in The Face of a Forfeiture Clause, 45 Geo. L. J. 200 (1957).
} 